\title{
Employment Generation and Asset Creation through MGNREGS: A Study of Harirampur Block of Dakshin Dinajpur District, West Bengal
}

\author{
Satyajit Saha \\ Department of Social Work, Assam University (Central), Silchar, Assam, India \\ Corresponding author: satyajitmsw@gmail.com
}

Received: 14-04-2019

Revised: $12-07-2019$

Accepted: 25-08-2019

\begin{abstract}
NREGA, enacted in 2005, forms the basis of a massive employment guarantee scheme, implemented throughout India, with two main objectives - to enhance the livelihood security of people in rural areas, and to boost the rural economy. It complies the former by guaranteeing unskilled wage employment to the adult members of the rural households who have volunteered willing to do unskilled manual work. The present study is based on secondary data from MGNREGS website, which is the On-line official website \& records of Ministry of Rural Development and Panchayat Raj, Government of West Bengal and also Ministry of Rural Development, Government of India. It reveals that the performance of Harirampur Block Progress Report during financial year: 2015-16, 2016-17, 2017-18 \& 2018-19 in terms of providing employment and generating assets to the rural households. Thus, this paper has critically analysed the progress of the programme for last four financial years. Analysis of data reflects that the programme has created huge employment opportunities in Harirampur block. It has also been successful in creating durable community assets as well as individual assets. The paper concludes with some suggestions for improvement for the both aspects.
\end{abstract}

Keywords: MGNREGA, Employment Generation, Livelihood Security, Assets Creation

National Rural Employment Guarantee Act (NREGA) 2005 is a unique policy intervention by the Government of India for providing 'livelihood security' to the resource poor people in rural India. Under the Act, the Governments are legally bound to provide 100 days guaranteed manual job or employment to every rural unskilled adult (job-card holder) who is willing to work at the prevailing minimum statutory wage rate. A number of Centrally Sponsored Schemes have been implemented under Rural Development Mission for welfare of the poor. But NERGA is one of the greatest experiments undertaken in India to eradicate rural poverty. The scheme has been launched to supplement the error and gaps of all previous schemes with the involvement of Panchayats, civil society and local administration. Poor families were targeted to give benefits of employments and livelihood to supplement their family income. The NREG Act came into force on February 2, 2006 and was implemented in three phased manner. In Phase I it was implemented in 200 of the most backward districts of the country. It was implemented more in an additional 130 districts in Phase II in 2007-2008. The Act also cover remaining 285 others districts of India from April 1, 2008 in Phase III. Thus it covers entire rural India. Harirampur Block of Dakshin Dinajpur district is a first phase district in West 
Bengal where MGNREGS was implementation started during 2006. The main aim of the Act was to create durable assets to augment land and water resources, improve rural connectivity and strengthen the basic needs of the rural poor. MGNREGS works are largely focused on land and water resources which include: irrigation provisioning and improvement, renovation of traditional water bodies, land development and drought proofing water harvesting and conservation, soil conservation and protection. These MGNREGA have the prospective to generate environmental benefits such as afforestation, ground water recharge, soil and water conservation, drought and floods control etc. The Act was implemented through the MGNREG scheme which was consciously attempted to counter weaknesses of earlier programs through several features in its design. It introduced a right-based framework with legislative backing from Government of India. It also incorporated time bound action to fulfil guarantee of work within 15 days of demand for work and a disincentive for nonperformance. The work guarantee can also serve other objectives: generating productive assets, protecting the environment, empowering rural women, reducing ruralurban migration and fostering social equity, among others etc. The Act also seeks to create employment generation by creating Assets for the villagers where they have their livelihood or nearby community assets by utilizing land and water resources, improve rural connectivity and strengthen the basic needs of the rural poor. MGNREGS works are largely focused on land and water resources which include: water harvesting and conservation, soil conservation and protection, irrigation provisioning and improvement, renovation of traditional water bodies etc.

The present study attempts to capture to what extent the employment was generated and durable assets are created during the recent last four financial year of implementation of MGNREGS in Harirampur Block. The study is based on secondary data, mainly from online website of MGNREGA, which are also the official records of Ministry of Rural Development and Panchayat Raj, Government of West Bengal and Government of India.

\section{Harirampur Block}

Harirampur Block is the most backward block of Dakshin Dinajpur district, It is a community development block under Gangarampur sub-division of Dakshin Dinajpur district of West Bengal. The area is generally flat and slightly undulating. Harirampur Block is bounded by Kushmandi Block on the north, Bansihari Block on the east, Gazole Block of Malda district on a part of the south, Itahar Block in Uttar Dinajpur district on the rest of the south and the west. It is located at $25^{\circ} 22^{\prime} 27^{\prime \prime} \mathrm{N} 88^{\circ} 16^{\prime} 04^{\prime \prime}$. It has 1 panchayat samiti, 6 gram panchayats, 98 gram sansads (village councils), 155 mouzas and 144 inhabited villages. It consist of six Gram Panchayat namely: (1) Bagichapur, (2) Bairhatta, (3) Gokarna, (4) Pundari, (5) Saiyadpur, and (6) Shirshi. Bengali was the mother-tongue of most of the population of Dakshin Dinajpur district, Besides Bengali language people also talk in Santali, Hindi language. As per Census: 2011, Harirampur Block had a total population of 136,853 , of which 131,832 were rural and 5,021 were urban. There were 69,058 (50\%) males and $67,795(50 \%)$ females. Population below 6 years was 19,389. Scheduled Castes numbered 29,853 (21.81\%) and Scheduled Tribes numbered 25,053 (16.85\%). As per 2014 District Statistical Handbook: in Harirampur CD Block, Hindus consist of 61,987 no. and formed $49.62 \%$ of the population. Muslims consist of 59,935 no. And formed $47.98 \%$ of the population. Christians consist of 952 no. and formed $1.64 \%$ of the population. And others consist of 2,053 and formed $1.64 \%$ of the population. As per the 2011 census, the total number of literates in Harirampur CD Block was 76,099 (64.67\% out of which males numbered 42,335 (71.45\%) and females numbered $33,764(58.00 \%)$ The gender disparity (the difference between female and male literacy rates) was $13.45 \%$.

The main sources of earnings are cultivation, agriculture labour and house hold industry work. The land is fertile for agricultural production, The Aman Paddy and Boro Paddy cultivation is the main cultivated crop grown in the area, besides there have been huge production of green vegetable. Harirampur Block had 92 primary schools, 13 middle school, 7 high schools, 8 higher secondary schools and 1 general degree college. As part of Government Health care delivery system, 
Harirampur Block had 1 rural hospital and 1 primary health centre, with total 42 beds and 19 family welfare sub-centres.

\section{Map of Harirampur Block}

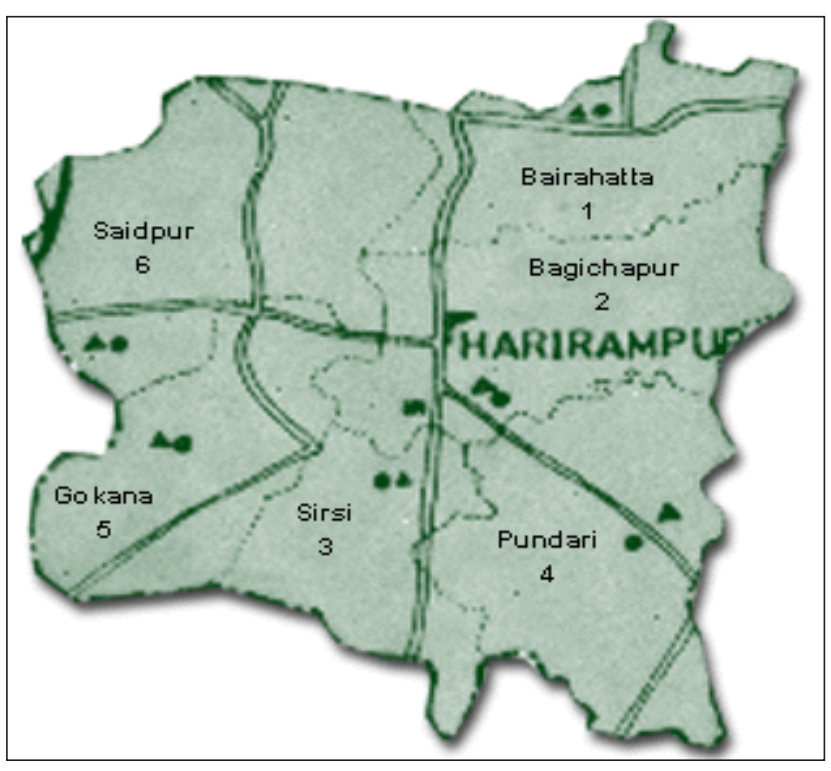

Map not to Scale

\section{Current Status of MGNREGS in Harirampur Block of Dakshin Dinajpur}

As per recent (June 2019) official record of MGNREGA total 22645 No. of Job Cards issued in Harirampur Block, out of which 21989 no. are active job card holders. And there have been 40110 no. of unskilled labour registered under MGNREGS out of which 21989 no. are active unskilled labour. $12.27 \%$ are active Schedule caste unskilled labour and $8.22 \%$ belongs to Schedule Tribe active unskilled labour.

The above table, (Table 1), shows the progress trend of Harirampur block from 2015-16 to 2018-19. During 2015-16 to 2018-19, there have been more than 6 times increase in person days from 115188 to 731442 . The average days of employment provided per Household also increases from $20.97 \%$ (2015-16) to $68.8 \%$ (2018-19). Total No of House Holds completed 100 Days of Wage Employment also increase 27 to 1735 which is more than 64 times increase compare to 2015-16 from 201819. Thus, there have been positive trends of upliftment in total household worked and individual worked in MGNREGS at Harirampur Block. As the person days increases there has been increase in completed work also which are more than 50 times increase of completed work from 267 during 2015-16 to 13546 during 201819. And consequently the financial expenditure also increases with Employment Generation and Assets Creation.

Table 1: Performance of MGNREGS in Harirampur Block of Dakshin Dinajpur District during financial year 2015-16 to 2018-19

\begin{tabular}{|c|c|c|c|c|c|}
\hline Sl. No & (I) Progress Report & FY 2018-19 & FY 2017-18 & FY 2016-17 & FY 2015-16 \\
\hline 1 & Person days Generated so far & $7,31,442$ & $4,40,678$ & $3,09,786$ & $1,15,188$ \\
\hline 2 & Average days of employment provided per Household & 68.8 & 50.97 & 42.36 & 20.97 \\
\hline 3 & Total No of HHs completed 100 Days of Wage Employment & 1,735 & 498 & 167 & 27 \\
\hline 4 & Total Households Worked & 10,631 & 8,645 & 7,313 & 5,492 \\
\hline \multirow[t]{2}{*}{5} & Total Individuals Worked & 17,138 & 12,853 & 8,896 & 7,306 \\
\hline & (II) Works Progress Report & & & & \\
\hline 6 & Total No. of Works Taken-up (New \& Spill Over) & 21,584 & 17,706 & 10,207 & 3,837 \\
\hline 7 & Number of Ongoing Works & 8,038 & 15,328 & 9,327 & 3,570 \\
\hline \multirow[t]{2}{*}{8} & Number of Completed Works & 13,546 & 2,378 & 880 & 267 \\
\hline & (III) Financial Progress Report & & & & \\
\hline 9 & Total Expenditure (₹ in Lakhs) & $1,643.86$ & 838.41 & 685.32 & 129.64 \\
\hline 10 & Wages (₹ In Lakhs) & $1,156.01$ & 710.93 & 601.33 & 67.36 \\
\hline 11 & Material and skilled Wages (₹ In Lakhs) & 487.85 & 127.48 & 79.69 & 58.89 \\
\hline
\end{tabular}

Source: wWw.nrega.nic.in (Official website of MGNREGS MIS data as on 22.06.2019). 


\section{MGNREGS as a Source of Employment Generation in Harirampur Block}

Employment generation among rural masses is the key objective of this programme which has always been given utmost priority since the beginning. The programme has undoubtedly generated huge wage employment in rural India by helping the poor in utilizing their physical work. It has been working as safety nets in rural fabric of the society providing employment opportunities during lean season's and percolating money to the hand of the rural people. A number of studies have been conducted to measure the effectiveness of MGNREGA on employment generation which shows varying results. These studies on Harirampur Block helped to identify critical gaps in programme implementation, creating scope for midcourse correction and improve in performance.

The table 2 shows that the total House Hold Employed during 2018-19 is 10631, Out of which $20.61 \%$ (2192) of the House Hold Employed attendance between (51-60) days, followed by $16.27 \%$ (1944) House Hold Employed attendance between (81-99) days, $18.28 \%$ (1730)House Hold Employed attendance equal to 100 days, 14.16\% (1506)House Hold Employed attendance between (61-70) days, 10.73\% (1141) House Hold Employed attendance between (71-80) days, and the rest others $19.87 \%$ (2113) of the House Hold attendance between (01 -50) days.

Analyzing the table it can be said that $16.32 \%(1730+5)$ House Hold employed more than or equal to 100 days, 63.80\% (6783) House hold employed between (51 -99) days. So, majority House Hold (63.80\%) get 51 to 99 no. of day's unskilled job in MGNREGS in Harirampur Block.

Again, this table also indicates, also indicates that out of total 731442 person days generated during $2018-19,24.04 \%$ (175910) person days generated had attendance between (81-99) days, followed by $23.65 \%$ (173000) person days generated had attendance equal to 100 days, $17.60 \%(128792)$ person days generated had

Table 2: Days wise Employment Provided under MGNREGS in Harirampur Block during Financial Year 2018-2019

\begin{tabular}{|c|c|c|c|c|c|c|c|c|c|c|c|c|c|c|c|c|c|c|c|c|c|c|}
\hline \multirow{2}{*}{ 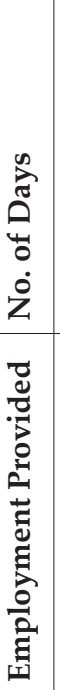 } & \multicolumn{2}{|c|}{ 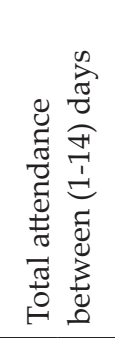 } & \multicolumn{2}{|c|}{ 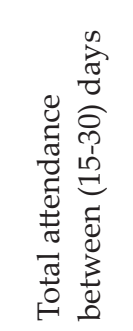 } & \multicolumn{2}{|c|}{ 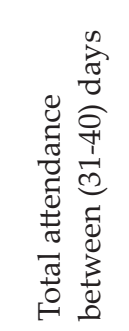 } & \multicolumn{2}{|c|}{ 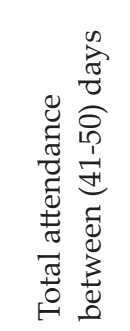 } & \multicolumn{2}{|c|}{ 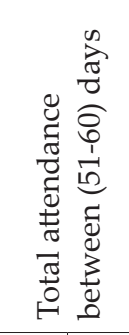 } & \multicolumn{2}{|c|}{ 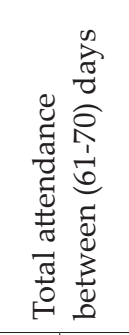 } & \multicolumn{2}{|c|}{ 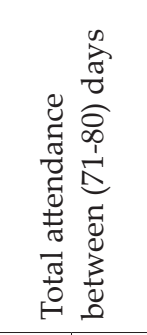 } & \multicolumn{2}{|c|}{ 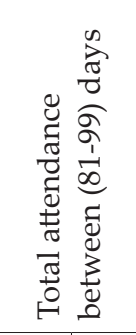 } & \multicolumn{2}{|c|}{ 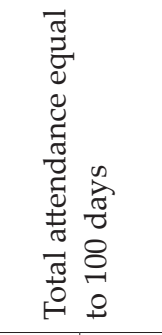 } & \multicolumn{2}{|c|}{ 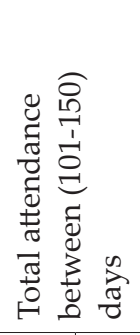 } & \multicolumn{2}{|c|}{ 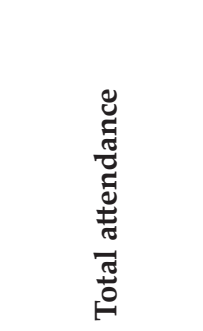 } \\
\hline & 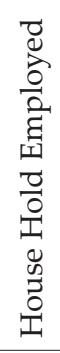 & 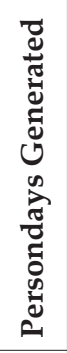 & 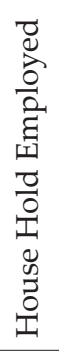 & 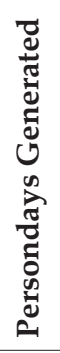 & 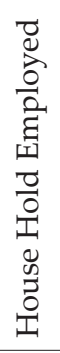 & 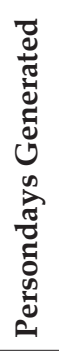 & 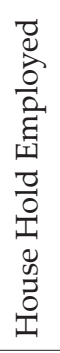 & 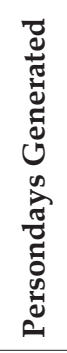 & 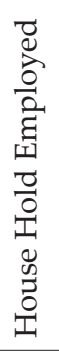 & 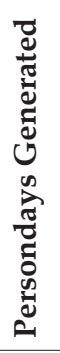 & 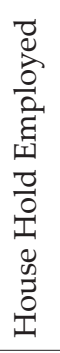 & 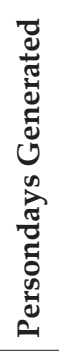 & 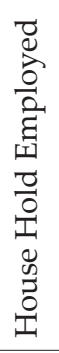 & 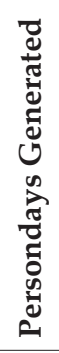 & 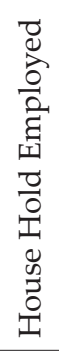 & 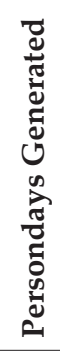 & 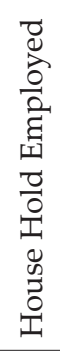 & 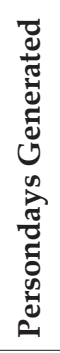 & 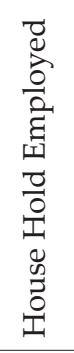 & 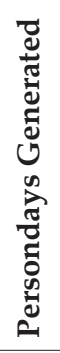 & 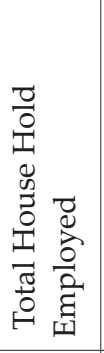 & 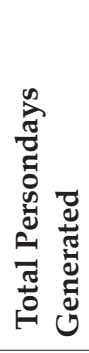 \\
\hline 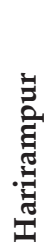 & $\begin{array}{l}\widehat{o} \\
\dot{0} \\
\stackrel{0}{0} \\
\stackrel{0}{0} \\
\stackrel{0}{0}\end{array}$ & 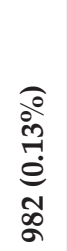 & $\begin{array}{l}\widehat{0} \\
\infty \\
\sigma \\
\infty \\
\infty \\
\infty \\
\sigma\end{array}$ & 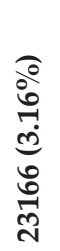 & 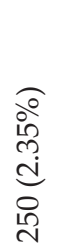 & 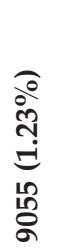 & 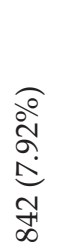 & 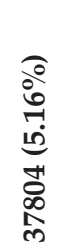 & 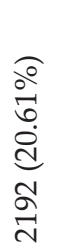 & 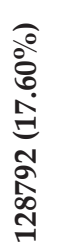 & 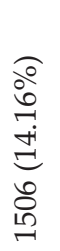 & 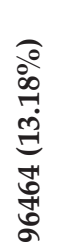 & 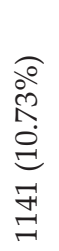 & 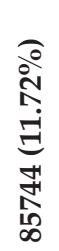 & 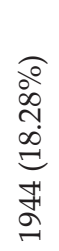 & 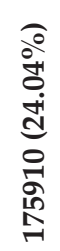 & 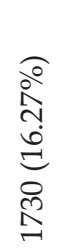 & 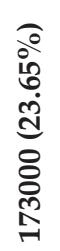 & $\begin{array}{l}\stackrel{\circ}{\circ} \\
\stackrel{+}{0} \\
\stackrel{2}{0}\end{array}$ & 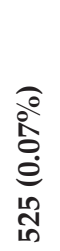 & $\begin{array}{l}\widehat{\circ} \\
\stackrel{8}{0} \\
\stackrel{0}{0} \\
\overrightarrow{0} \\
\stackrel{0}{0}\end{array}$ & 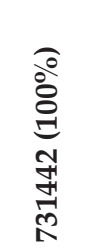 \\
\hline
\end{tabular}

Source: www.nrega.nic.in (Official website of MGNREGS MIS data as on 22.06.2019) 
attendance between (51-60) days, 13.18\% (96464) person days generated had attendance between (61-70) days, $11.72 \%$ (85744) person days generated had attendance between (71-80) days, and the rest others 9.70\% (71007) person days generated had attendance between (01 -50) days.

Therefore, analyzing the table it can be said that $23.72 \%$ $(173000+525)$ person days generated had covered100 or more than 100 days, $66.56 \%$ (486910) person days generated between (51- 99) days. Thus, we can say that in Harirampur Block majority $66.56 \%$ person days generated between (51-99) days through MGNREGS implementation.

\section{Creation of Assets through MGNREGS in Harirampur Block}

Section 2 of Schedule-I of the MGNREG Act vividly expresses that 'Creation of durable assets and strengthening the livelihood resource base of the rural poor shall be an important objective of the Scheme'. Creation of sustainable assets that strengthen the livelihood resource base of rural areas is one of the key objectives of MGNREGA. This article will focus on the trend of assets created under MGNREGS as sustainable resource base in Harirampur Block.

Table table 3 shows that there has been creation of 13547 no. of durable Assets in different categories in Harirampurblock of West Bengal during the last financial year: 2018-19 under MGNREGS. The data indicates that the first priority was given to the Individual land development where $95.49 \%$ (12938) assets were created for empowering more land to develop cultivation area, Followed by $3.67 \%$ (498) Drought proofing as Assets creation, $0.31 \%$ (42) for Water conservation and Water harvesting, Rural Connectivity $0.22 \%$ (31), Rural Sanitation $0.15 \%$ (19), Micro Irrigation work $0.08 \%$ (11) and so on.

Hence, from the table it can be said that Assets Creation mainly for improvement in agriculture and allied related work is main focus for sustainable development of the area. So, priority was given to work on individual lands, Drought proofing, Water Conservation and Water Harvesting, Rural connectivity mainly. Further, it can be observed that the total number of assets created were significantly increased during this period (201516 to 2018-19), which is more than 50 times increase of completed work from 267 to 13546 as shown in table 1. Thus, we can say that MGNREGS plays a vital role in Generating Employment and Assets creation in Harirampur Block of Dakshin Dinajpur.

\section{CONCLUDING DISCUSSION}

MGNREGS has not only set good examples in rural India in creating opportunities for employment but also created durable assets in many parts of the country like Harirampur Block which in turn further improved resource basefor livelihoods for rural masses. It has also created scope of strengthening PRIs which are primarily responsible to implement the programme.

Table 3: Assets Created under MGNREGS at Harirampur Block during financial year: 2018-19

\begin{tabular}{|c|c|c|c|c|c|c|c|c|c|c|c|}
\hline 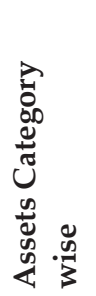 & 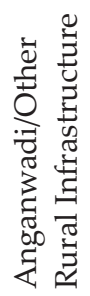 & 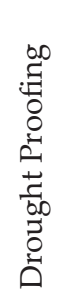 & 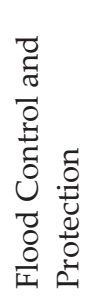 & 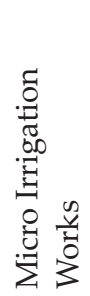 & 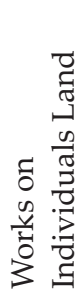 & 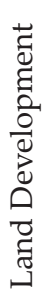 & 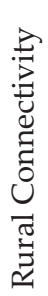 & 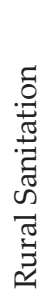 & 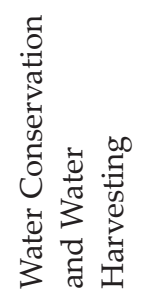 & 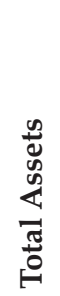 & U⿱艹⿹勹巳 \\
\hline 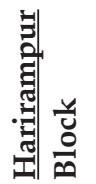 & $\begin{array}{l}\overparen{0} \\
\stackrel{0}{0} \\
\stackrel{0}{e} \\
\stackrel{0}{\sigma}\end{array}$ & $\begin{array}{l}\widehat{0} \\
\stackrel{\hat{Q}}{b} \\
\stackrel{0}{0} \\
\infty \\
\text { के }\end{array}$ & 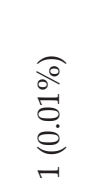 & 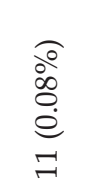 & 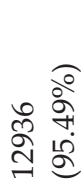 & 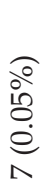 & 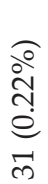 & $\begin{array}{l}0 \\
i 0 \\
i 0 \\
\stackrel{0}{0} \\
0 \\
0\end{array}$ & 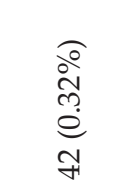 & & 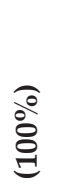 \\
\hline
\end{tabular}

Source: www.nrega.nic.in (Official website of MGNREGSMIS data as on 22.06.2019 
In Harirampur Block the rate of completion of work gradually decreases in the recent year 2018-19 compare to other last three years (table 1). Therefore, the implementing agencies need to be more committed to implement the Act in a provocative manner so as to ensure 100 days of employment to most of the House Holds under MGNREGS as stipulated in the Act. However, to go ahead with this success rate it needs to take the following suggestive steps on completion of works with in the speculated time period.

* Making viable Annual Action plan (AAP) by participatory planning in the Gram Sabha,

* Capacity building of the implementation agency and manpower such as super-visor, technical persons, other professionals.

* Increase the numbers of manpower for proper monitoring at each and every implemented level.

* Meeting the gap of Fund flow by proper labour budget and wage payment within 15 days of work.

* Increasing convergence of work with other departments for proper implementation of the project.

* Maintaining Transparency and accountability by organizing Social Audit of different NREG Schemes.

\section{REFERENCES}

Census of India. 2011. "District Census Hand Book, Dakshin Dinajpur", Series-20, Part- XII-B, Directorate of Census Operations, Govt. of W.B, Kolkata.
Dutta, S. 2009. "NREGA in West Bengal: Success and Challenges", Kurukshetra, 58(52).

Govt. of India. 2004. "District Human Development Report-Dakshin Dinajpur" Planning Commission, Govt. of India.

Govt. of W.B. 2014. "District Statistical Handbook Dakshin Dinajpur 2014" Department of Planning, Statistics and Programme Implementation, Government of W.B.

MGNREGA. 2014. "Report to the People", Ministry of Rural Development, Govt. of India, New Delhi.

MGNREGA. 2015. "Report to the People", Ministry of Rural Development, Govt. of India, New Delhi.

MGNREGA Sameekha. 2012. "An Anthology of Research Studies on the Mahatma Gandhi National Rural Employment Guarantee Act, 2005, 2006-2012", Ministry of Rural Development, Government of India.

MGNREGA. 2013. "Operational Guideline-2013", $4^{\text {th }}$ edition, Ministry of Rural Development, Government of India.

MGNREGA Sameekha II. 2015. "An anthology of Research Studies (2012-2014)", United Nations Development Programme, New Delhi.

MGNREGS. 2017. Performance, Initiatives and Strategies (FY 15-16 \& FY 16-17), Mahatma Gandhi NREGA Division, Ministry of Rural Development, 2005, Govt. of India, www. nrega.nic.in

MGNREGA. 2019. "Annual Master Circular 2019-20”, Ministry of Rural Development, Government of India.

MGNREGS website, "www.nrega.nic.in" Ministry of Rural Development, Government of India.

Ministry of Rural Development, Govt. of India. (2006 - 07), Annual Report.

Ministry of Rural Development, Govt. of India. (2008- 09), Annual Report. 